\title{
Autoritaarinen ei ymmärrä Engeströmiä
}

Olen nähnyt työssäni, eri ikäisten opettajana sekä perus- että täydennyskouluttajana miten vähän itse asiassa lasten ja aikuisten oppiminen eroavat toisistaan. Molemmissa olennaisimmat asiat ovat samat, jos pyritään opettamiseen, missä tieto ymmärretään ja saatetaan muotoon, jossa sitä voi soveltaa.

Mikä muu on tärkeää informaatioajan opettajan työssä?

Antti Kauppi tarkastelee Aikuiskasvatus -lehden numerossa 3/83 Yrjö Engeströmin opettamisen ajattelumallia kirjoituksessa Lasten opettaminen - aikuisten opettaminen. Kaupin näkemys lasten opettamisesta on mielestäni yhtä väärä kuin hänen käsityksenä psykologis-kognitiivisesta oppimisprosessista.

Ennen kuin pyrin osoittamaan Kaupin ajatusten virheellisyyttä lasten opettamisesta esitän kolme tekijää, joiden vuoksi mielestäni Engeströmiä on suotta kaltoin kohdeltu, väärin ymmärretty.

1) Hyvän teorian tunnistaa siitä, että se on palautettavissa todellisuuteen ja sillä on sovellutusarvoa. Engeströmin ajatuksia ymmärtämättömiltä puuttuu vuorovaikutuksellista näkemystä opetukseen, he tarkastelevat uutta asiaa vanhoin ajatusmallein. Ei ihme, ettei sitä tavoita.

2 ) Engeströmille opettaja ei ole vain tiedon siirtäjä, hän on oppimisprosessin vaikuttaja, auktoriteetti. Opettaja on ihminen tässä ajassa, hän edustaa jotakin paljon enemmän kuin pelkkää tietoa. Tällainen opettajakuva pelottaa. Vuorovaikutuksellisuuteen kasvaminen on kipeä asia, ei ihme, jos sitä kieltäytyy ymmärtämästä. Sen ymmärtämättömyys paljastaa mielestäni koko oppimisprosessin ymmärtämättömyyden.
3) Informaatioaikakauden ihmiselle oman opiskelun, tiedonsaannin itsesäätelykyky on henkisen tasapainon kannalta välttämätöntä. Tieto, jota ihminen ei ymmärrä, muodostuu kestämättömäksi taakaksi, se vääristää todellisuutta, koska epämääräistä ahdistusta on suojeltava.

Kyetäkseen ohjailemaan opiskeluaan, ihmisellä on oltava oppimisen struktuuri. Sen pohjalta voi hahmottaa omaa erityistapaansa omaksua asioita.

Psykologis-kognitiivinen oppimisprosessin tarkastelu on syvällisintä ja laajinta oppimisen tarkastelua, mitä tähän asti on esitetty.

Ja nyt perusteluihin, joilla väitän Antti Kaupin kirjoituksen Lasten opettaminen - aikuisten opettaminen olevan vanhalla asenteella uutta asiaa tarkastelevan ihmisen kirjoitus.

Kauppi kuvaa aikuisopetusta: 'Opettaminen ei sinänsä edellytä oppimista, ja usein jopa kasaa esteitä mielekkään oppimisen tielle." Täsmälleen samasta syystä estyy lapsen oppiminen. Lapsilla vuorovaikutuksen ymmärtämättömyys on vielä tuhoisampaa. Se estää ajattelun kehittymisen myöhemmin, oppiminen estyy tai hidastuu juuri niillä elämän alueilla, joilla tuputtamista on tapahtunut.

Aikuinen odottaa, että hänen itsemääräämisoikeuttaan kunnioitetaan", sanoo Kauppi. Jos aikuinen ei tiedä, että näin on myös lapsella, hän ei ole opettaja vaan oppimisen hävittäjä.

Niin oppimisilmapiiri kuin yhteinen oppimisen ja työn suunnittelu ovat keskeisiä asioita myös lasten opetuksessa. Valmiit opetussuunnitelmat ja oppimateriaalin orjallinen noudattaminen estävät oppimisen, tuhoavat oppimisen motivaation. On totta, että lapsen tarpeista 
lähtevä opetus vaatii opettajalta paljon tietoa ja erilaisten opettamismenetelmien hallintaa, mutta niinpä opettaminen onkin nostettava taiteeksi ja tieteeksi. Ajattelukapasiteetti on informaatioajan ihmisen todellista omaisuutta. Siihen kannattaa sijoittaa.

Opettamisen tapa opettaa enemmän kuin opetettava asia. Elämykset, rohkeus tarttua uusiin asioihin, kyky luoda kontakteja, toimia yhdessä toisten kanssa ovat tekijöitä, jotka saavat aikaan oppimista. Niillä on varma siirtovaikutus.

'’Prosessin jatkuvuuden kannalta olennainen vaihe on arviointi", kirjoittaa Kauppi. Niin on lapsellakin. Sinä osaat! Sinä löysit! Rohkeutesi ja ponnistelusi tuottivat tuloksia. Oman itsensä uusien ulottuvuuksien tunnistaminen ryhmän avulla on tärkeää.

Kauppi siteeraa Knowlesin (miksi ihmeessä juuri Knowles Engeströmiä vastaan!) sisältökeskeistä oppimisen mallia, mitä muka lasten opetus on: opettaja päättää etukäteen, mitä tietoja ja taitoja tarvitsee opettaa, järjestää tämän sisällön loogisiin osasiin jne. Jos se logiikka on aikuisen logiikkaa, jos toiminnassa ei oteta huomioon lapsen vastaanottokykyä ja elämyksellistä osuutta, opetetaan oppimiselle esteitä. Se mikä n ä y t t ä ä autoritaariselta opettamisessa, ei hyvässä opetuksessa ole sitä. 'Looginen eteneminen pienin osin" voi tapahtua joko lapsen ehdoin tai aikuisten ehdoin.

Vuorovaikutuksellisen opetuksen ymmärtäminen edellyttää syvää tietoa lapsesta, vahvaa teoriaa oppimisprosessista sellaisena kuin se todellisuudessa on. Vahva tieto oppimisprosessista on juuri se mitä me tarvitsemme voidaksemme luoda tilanteenmukaisen sovellutuksen opetukselliseksi muodoksi.

Heikolla teorialla, kapealla näkemyksellä oppimistapahtumasta päädytään ulkokohtaiseen opettamistapaan, joka ei suo väljyyttä toimia lapsen ehdoin (tai aikuisen opiskelijar. ehdoin).

Teoreettisuuden vastakohta on siis ulkokoh. tainen, annetun mallin mukaan toimiminen tilanteessa kuin tilanteessa. (Tätä ei ole Engeströmin opettaminen.) Opetussuunnitelma ja oppimateriaali määräävät toiminnan, joku jossain sanoo, että näin pitää opettaa. Mutta syvää näkemystä - tietoa - siitä miksi niin tehdään, ei tarvita. Ei tarvita oppimisprosessin ymmärtämistä.

Teorian hallinta vapauttaa toimimaan oppimistapahtumassa sen ehdoin, syntyy luova prosessi.

Tässä on opettajan auktoriteetti: hän hahmottaa todellisuutta ajatuksellaan laajemmin ja syvemmin kuin oppilaansa asettumatta kuitenkaan oppijan eteen. Tässä on oppimisen paradoksi: opettaja ympäröi - ymmärtää oppimisprosessin ja häipyy tämän jälkeen tuloksellisen oppimisen taustalle seuraajaksi.

Mitä muuta opettajan tulee tietää kuin oppimisen struktuuri? Muu on hänen persoonallisten kykyjentä: intensiivisyytensä, intuitionsa ja ajattelukykynsä varassa. Niiden avulla hän rakentaa oppimisilmaston, kuhunkin tilanteeseen sopivan opettamisen muodon ja annostelee välittämäänsä asiaa. Tätä persoonallista kykyä on nimitettävä opettajan auktoriteetiksi. Sitä voi olla vain kuvaamassani vuorovaikutuksellisessa opetuksessa.

Tämä on olennaisin asia oppimisessa ja tässä olennaisimmassa aikuisten ja lasten oppiminen ei toisistaan eroa. Mutta täytyy olla syvää teoreettista ymmärtämystä oppimisprosessista ennenkuin tämän tajuaa. Knowlesin ajattelumallilla ei siihen yllä.

Jos Engeström paikoin esittää vanhalla tavalla uutta näkemystä, jota tässä nimitän vuorovaikutukselliseksi opetukseksi, se johtuu siitä, että uusi kieli uudelle asialle on vielä syntymättä. Rakentaessani paraikaa kirjaa Vuorovaikutus/Kasvu olen todennut miten puhuessani kasvusta puhun samanaikaisesti siitä mikä itsessäni ja ympäristössäni on elämää.

Elämää tunnistaa vain sellainen, joka osaa hiljentyä sen eteen. Se on aina kokonainen tapahtuma. Pirstaleisen, vanhan tarkastelumallin omaksuneelle se on mahdotonta. 